\title{
The Effect of Generic Features of Task on L2 Learners' Oral Performance
}

\author{
Davud Kuhi \\ Islamic Azad University Maragheh Branch, Maragheh, Iran \\ Email: davudkuhi@yahoo.com \\ Asghar Salimi \\ Payam Nour University, Shahindej Branch, Shahindej, Iran \\ Email: Asgharsalimi356@gmail.com \\ Ali Shafaei \\ Islamic Azad University Maragheh Branch, Maragheh, Iran \\ Email: Shafaeiali64@gmail.com
}

\begin{abstract}
A growing body of research in the past decade has been devoted to the investigation of various aspects of Task-based language teaching (TBLT) (Ellis, 2003, 2005; Foster \& Skehan, 1996, 1999; Skehan \& Foster, 1997, 1999; Tavakoli \& Foster, 2008; Rahimpour, 1999, 2008, 2010; Robinson, 2001, 2007, Salimi \& Yousefi, 2009; Salimi \& Dadashpour, 2011; Dadashpour, 2011). Having reviewed the studies conducted on tasks, it was revealed that there is gap in the literature on the effects of generic features of tasks on L2 learners' oral and written performance. This paper aims at investigating the effect of generic features of tasks on L2 learners' oral performance in EFL context. The participants of the study were 30 intermediate learners of English as a foreign language. The participants were asked to perform on three tasks with different generic features. Their oral performance on the tasks were recorded and analyzed according to the measures introduced by Ellis, 2008. ANNOVA was employed as the statistical means of analysis. The statistical analysis of the collected data revealed the generic features of task have no significant effect on the performance of $\mathrm{L} 2$ the learners in terms of accuracy, fluency, and complexity. The paper carries significant implications for SLA researchers, syllabus designers, and language teachers.
\end{abstract}

Index Terms — task-based language teaching and learning, accuracy, fluency, complexity, genre

\section{INTRODUCTION}

Recently task-based language teaching and learning has attracted many SLA researchers, testers, teachers, and syllabus designers' attention and consequently a lot of studies have been conducted in the field (Ellis, 2003, 2005; Foster \& Skehan, 1996, 1999; Skehan \& Foster, 1999; Tavakoli \& Foster, 2008). Task-based approaches to second language teaching focus on the ability of a learner to perform target-like tasks without any explicit teaching of grammatical rules (Rahimpour, 2008). Task-based L2 performance is an interesting subject in itself and worthy of empirical investigation, but as tasks are widely used in language teaching and language exams, learning more about their impact might have practical value (Tavakoli \& Foster, 2008).

Genre analysis has attracted so much attention since the early 1980 . Genre, which has traditionally been a literary concept, has recently become a popular framework for analyzing the form and rhetorical function of non-literary discourse (Hyland, 2002). Linguistics and language teachers have tried to apply genre-centered-approaches to the analysis of written and spoken discourse in order to provide satisfactory models and descriptions for academic and scientific text and also help non-native speaker students to enhance their ability of understanding and proper production of text (Dudley- Evans, 1986). Swales (1990) asserted that genre analysis essentially is based on two central assumptions. First, the feature of a similar group of text depends on the social context of their creation and use. Second, those features can be described in a way that relates a text to other texts like it. Hyland (2003) introduced three broad, overlapping schools of genre theory: New Rhetoric approach, ESP approach, and Sydney School. From among these three approaches to genre, the present study is based on the ESP approach since it is more linguistic than the others.

\section{LITERATURE REVIEW}

\section{A. Task-based Language Teaching}

Task-based language teaching and learning has become an important area of research in second language research. Many scholars and researcher have investigated different aspects of TBLT (Ellis 2003, 2005, 2009; Foster \& Skehan 1996, 1999; Long 1985, 2007; Robinson 1995, 2001, 2007; Rahimpour 1997, 2002, 2008, 2010, 2011). According to 
Rahimpour (2010)TBLT focuses on the ability to perform a task or activity without explicit instruction of language forms. It is also argued by many SLA researchers that TBLT creates more favorable condition for the development of SL (Long \& Crooks 1992; Robinson 1995, 2001; Rahimpour 1997, 2007, 2008, 2010).Ellis (2009) defines TBLT as:

An approach for teaching second or foreign language that seems to engage learners in interactionally authentic language use language by getting learners to perform a series of tasks. This approach aims to enable learners to acquire a new language system as well as to proceduralize their existing knowledge. In other words, this approach tries to force L2 learners to use their own linguistic resources to learn a new language

\section{B. Genre Analysis}

The last decade has seen increasing attention to the notion of genre and its application in language teaching and learning. This interest has been driven by a dual purpose. The first is a desire to understand the relationship between language and its context of sue. That is, how individuals use language to orient to and interpret particular communicative situations and the way these uses change over time. The second is to employ this knowledge in the service of language and literacy education. This second purpose both complements research in New Literacy Studies, which regard literacy as social practice (Barton \& Hamilton, 1998; Gee, 1996), and encourages us to explore language and pedagogies in ways that move beyond narrowly conceived formal and cognitivist paradigms (Hyland, 2002). According to Bhatia (2002) genre analysis can be viewed from two different perspectives: it may be seen as a reflection of complex realities of the world of institutionalized communication, or it may be seen as a pedagogically effective and convenient tool for the design of language teaching programs, often situated within simulated contexts of classroom activities. Genre analysis has always been a multi-disciplinary activity attracting attention not only from linguists (both applied and computational), discourse analysts, communication experts and rhetoricians, but also from sociologists, cognitive scientists, translators, advertisers, and plain English campaigners.

\section{Schools of Genre}

Hyland (2003) introduced three broad, overlapping schools or approaches of genre theory: a) The New Rhetoric Approach, b) Sydney School, c) ESP Approach. The ESP approach to genre is more linguistic in orientation and sees genre as a class of structured communicative events employed by specific discourse communities whose members share broad social purposes. These purposes are the rationale of a genre and help to shape the ways it is structured and the choices of content and style it makes available. This approach steers between these two views. Like the New Rhetoricians, it employs Bakhtinian notions of intertextuality and dialogism, but it also draws heavily on Systemic Functional understanding of text structure and, more sparingly, on Vygotskian principles of pedagogy. In fact, with its emphasis on communicative purpose and the formal properties of texts, the ESP approach might be seen as an application of SFL (Bloor, 1998), although it lacks a systemic model of language and does not make extensive use of a satisfied, metafunctional grammar. Genre here comprises a class of structured communicative events employed by specific discourse communities whose members share broad communicative purposes (Swales, 1990). These purposes are the rationale of genre and help to shape the way it is structured and the choices of content and style it makes available (Hyland, 2002).

\section{Definition of Genre}

Swales (1990) offered a definition of genre from ESP approach. He defined genre as:

A genre comprises a class of communicative events, the members of which share some set of communicative purposes. These purposes are recognized by the expert members of the parent discourse community, and thereby constitute the rationale for the genre. This rationale shapes the schematic structure of the discourse and influences and constraints choice of content and style. Communicative purposes are both privileged criterion and one that operates to keep the scope of a genre as here conceived narrowly focused on comparable rhetorical action. In addition to purpose, exemplars of genre exhibit various patterns of similarity in terms of structure, style, content, and intended audience. If all high probability expectations are realized, the exemplar will be viewed as prototypical by the parent discourse community. The genre names inherited and produced by discourse communities and imported by others constitute valuable ethnographic communications, but typically need validation (Swales, 1990, p: 58).

\section{E. Task Studies}

Several studies have been conducted to investigate the effects of different aspects task and task characteristics on L2 learners' oral and written performance (Crooks 1989; Bygate, 1996; Foster \& Skehan, 1996; Skehan \& Foster, 1999; Yuan \& Ellis, 2003; Tavakoli \& Skehan, 2005; Rahimpour, 2007, 2008; Dadashpour, 2011; Salimi \& Dadashpour, 2011). Skehan \& Foster (1999) investigated the effects of task structure and processing load on L2 learners' performance on a narrative retelling task. The results of the collected data showed that the structured task generated more fluent speech in all four conditions. The complexity of language was influenced by processing load; greater complexity was attained when a non-simultaneous condition (fourth condition) was involved. For accuracy, neither task nor condition showed significant effects. Tavakoli \& Skehan (2005) conducted a study in which they explored the influence of planning time conditions, task structure and language proficiency on task performance. Results indicated that the structured tasks generated more accurate and more fluent language than the unstructured tasks. Rahimpour 
(2007) studied the effect of task complexity on L2 learners' oral performance. The results showed that there-and-then task (complex task) led to more accuracy while here-and-now task (simple task) led to more complexity. In terms of fluency, here-and-now task led to more fluency than there-and-then task.

\section{ReSEARCH Question AND HypotheseS}

On the basis of the above literature review, the following research question and hypotheses were addressed in this study:

R.Q 1: What is the effect of generic features of task on L2 learners' oral performance?

HO: There is no significant difference between generic features of task and learners' accuracy, fluency, and complexity in oral performance.

H1: Generic features of cause/effect task would lead to less accuracy in L2 learners' oral performance than the generic features of narrative and descriptive tasks.

H2: Generic features of descriptive task would lead to more fluency in L2 learners' oral performance than the generic features of narrative and cause/effect tasks.

H3: Generic features of cause/effect task would lead to more complexity in L2 learners' oral performance than the generic features of narrative and descriptive tasks.

\section{METHOD}

\section{A. Participants}

The Participants of the study were 30 English language learners. They were both male and female and they were studying English at Iran National Language Institute in Miyandoab, West Azerbaijan, Iran. They aged between 17 and 30. To ensure about their homogeneity and their proficiency level, a pre-test was administered to the students of the intermediate level. The participants of this study were selected randomly on the basis of their performance on the pretest.

\section{B. Materials}

In task studies carried out so far, the most frequent and common task used in the studies has been the narrative task (Foster \& Skehan, 1996; Skehan \& Foster, 1999). According to Tavakoli \& Skehan (2005) narrative tasks refer to those stories based on a sequenced set of picture prompts which are given to participants to elicit language performance. In this study narrative task was used along with descriptive and cause/effect task to fulfill the purpose of this study. The tasks were chosen because they have different generic features. Attempts were made to find those picture series which were clear enough and had a suitable length, weren't too challenging for the learners at intermediate proficiency level, and were interesting and culturally familiar for the participants. Finally, the task used in the study was chosen as the data collection instrument because it mostly fit the purpose of this study and it could be used for the three tasks with generic features, i.e., narrative, descriptive, and cause/effect tasks.

\section{Procedure}

For collecting the data, the participants were asked to perform the tasks as following. First, they were asked to perform the narrative task. They were asked to look at the picture and tell the story of the pictures. Then, they were asked to perform the second task, descriptive task. At this phase, they were asked to describe the pictures. They participants were asked to give a description of what they saw in the pictures. Finally, they were asked to perform the third task, cause/effect task. The researcher asked them some questions about the pictures and the participants answered them orally. The collected written data were analyzed in terms of accuracy, fluency, and complexity measures introduced by Ellis (2008).

\section{RESULTS}

The collected oral data from the participants were measured according to three elements of oral performance namely accuracy, fluency, and complexity. In order to test the hypotheses of the study and find the way the generic features of task affect L2 learners' oral performance in terms of accuracy, fluency, and complexity, the raw scores of the participants were fed into computer software SPSS (version 16) for more analysis. ANOVA was employed to compare the means of the raw scores between and within three groups.

\section{A. Comparison of the Means of Accuracy, Fluency, and Complexity in Cause/Effect Task}

Table 4.1 shows the mean differences between accuracy, fluency, and complexity of L2 learners' oral performance in cause/effect task. 
TABLE4.1.

COMPARISON OF THE MEAN OF ACCURACY, FLUENCY, AND COMPLEXITY IN CAUSE/EFFECT TASK

\begin{tabular}{|l|l|l|l|}
\hline & $\mathrm{N}$ & Mean & Std. Deviation \\
\hline Accuracy & $\mathbf{3 0}$ & $\mathbf{0 . 3 5 6 3}$ & $\mathbf{0 . 1 5 1 4 4}$ \\
\hline Fluency & $\mathbf{3 0}$ & $\mathbf{8 9 . 8 1 8 3}$ & $\mathbf{1 7 . 6 6 3 8 1}$ \\
\hline Complexity & $\mathbf{3 0}$ & $\mathbf{3 6 . 6 8 4 0}$ & $\mathbf{3 . 9 6 0 5 3}$ \\
\hline Total & $\mathbf{9 0}$ & $\mathbf{4 2 . 9 5 2 9}$ & $\mathbf{3 8 . 2 7 3 9 5}$ \\
\hline
\end{tabular}

According to table 4.1, the mean of L2 learners' written production in fluency (89.81) is more than the mean of accuracy (0.35) and complexity (36.68). In other words, the generic features of cause/effect task have the most effect on fluency.

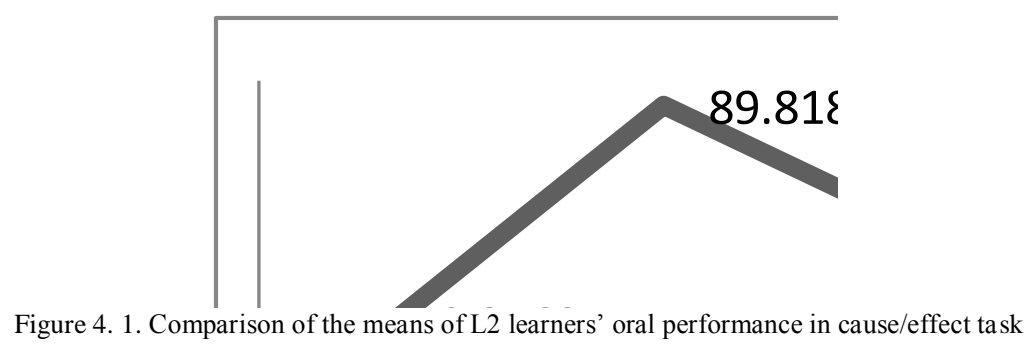

Figure 4.1 clearly presents the mean difference of L2 learners' oral performance in cause/effect task in terms of three linguistic domains of accuracy, fluency, and complexity.

B. Comparison of the Means of Accuracy, Fluency, and Complexity in Narrative Task

Table 4.2 presents the means of L2 learners' oral performance in narrative task.

TABLE 4.2.

COMPARISON OF THE MEAN OF ACCURACY, FLUENCY, AND COMPLEXITY IN NARRATIVE TASK
\begin{tabular}{|l|l|l|l|}
\hline & $\mathrm{N}$ & Mean & Std. Deviation \\
\hline Accuracy & $\mathbf{3 0}$ & $\mathbf{0 . 4 2 8 7}$ & $\mathbf{0 . 1 8 8 2 5}$ \\
\hline Fluency & $\mathbf{3 0}$ & $\mathbf{8 7 . 4 0 3 3}$ & $\mathbf{1 8 . 2 1 6 0 3}$ \\
\hline Complexity & $\mathbf{3 0}$ & $\mathbf{3 8 . 7 8 6 7}$ & $\mathbf{3 . 8 6 3 4 7}$ \\
\hline Total & $\mathbf{9 0}$ & $\mathbf{4 2 . 2 0 6 2}$ & $\mathbf{3 7 . 3 3 4 1 8}$ \\
\hline
\end{tabular}

According to table 4.2, the mean of fluency (87.40) is more than the means of means of accuracy $(0.42)$ and complexity (38.78). In other words, the generic features of narrative task have the most effect on L2 learners' oral fluency.

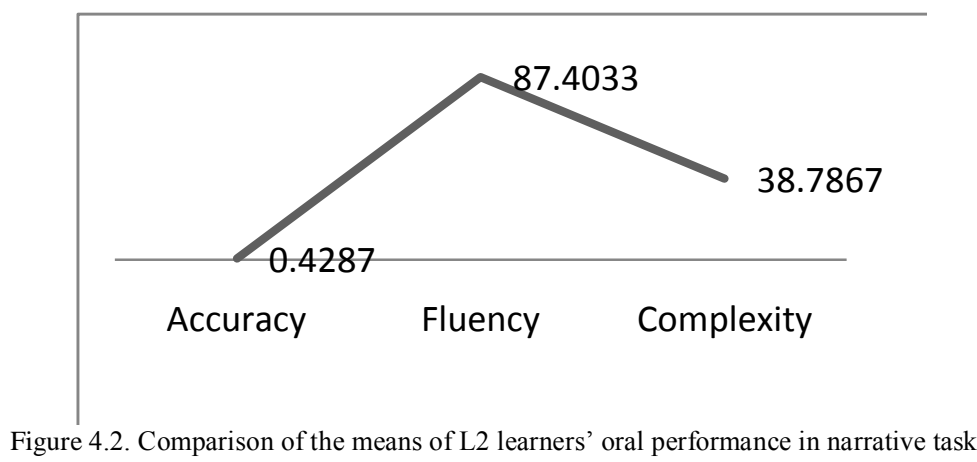

Figure 4.2 clearly presents the mean differences of 12 learners' oral performance in narrative task in terms of accuracy, fluency, and complexity.

C. Comparison of the Means of Accuracy, Fluency, and Complexity in Descriptive Task

Table 4.3 clearly shows the means of L2 learners' oral performance in terms of accuracy, fluency, and complexity in descriptive task. 
TABLE 4. 3 .

COMPARISON OF THE MEAN OF ACCURACY, FLUENCY, AND COMPLEXITY IN DESCRIPTIVE TASK
\begin{tabular}{|l|l|l|l|}
\hline & $\mathrm{N}$ & Mean & Std. Deviation \\
\hline Accuracy & $\mathbf{3 0}$ & $\mathbf{0 . 4 5 2 7}$ & $\mathbf{0 . 1 7 3 7 0}$ \\
\hline Fluency & $\mathbf{3 0}$ & $\mathbf{8 4 . 8 9 7 0}$ & $\mathbf{1 6 . 1 3 9 8 0}$ \\
\hline Complexity & $\mathbf{3 0}$ & $\mathbf{3 9 . 1 0 6 0}$ & $\mathbf{3 . 5 8 6 1 4}$ \\
\hline Total & $\mathbf{9 0}$ & $\mathbf{4 1 . 4 8 5 2}$ & $\mathbf{3 5 . 9 6 9 0 2}$ \\
\hline
\end{tabular}

According to table 4.3, the mean of fluency (84.89) is greater than the means of means of accuracy (0.45) and complexity (39.10). That is, the generic features of narrative task have the most effect on L2 learners' oral fluency.

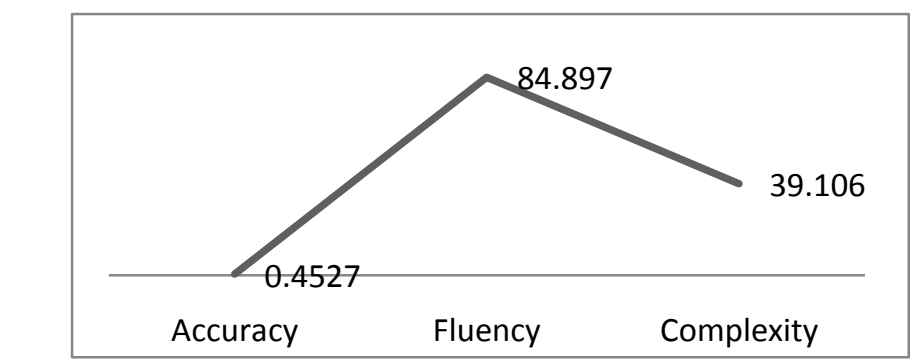

Figure 4.3. Comparison of the mean of L2 learners' oral performance in descriptive task

Figure 4.3 presents the means of accuracy, fluency, and complexity of L2 learners' oral performance in descriptive task.

\section{DISCUSSION}

Regarding the effects of generic features of task on L2 learners' written production in terms of accuracy, the results of this study showed that generic features of task did not have a significant effect on L2 learners' written accuracy. The findings of the in terms of accuracy are in line with the findings of the study conducted by Skehan \& Foster (1999) and Rahimpour \& Mehrang (2010). However, the findings of this study are in contrast with the findings of the studies like Iwashita, et al. (2001) and Tavakoli \& Skehan (2005). Skehan and Foster (1999) found out that accuracy of the performance is affected by task structure only if learners have the opportunity to engage in some kind of pre-task activity prior to task performance. As a result, it can be concluded that task structure had no effect on the accuracy of the performance in the current study because the participants were not involved in any kind of pre-task activities before they performed the tasks.

Considering the effect of generic features of task on L2 learners' written production in terms of fluency, the results of the data analysis revealed that there was no significant difference between generic features of task and L2 learners' written production in terms of fluency. The finding of the present study in terms of fluency is consistent with Iwashita et al. (2001), Tavakoli \& Foster (2008), and Rahimpour \& Mehrang (2010). However, the finding of the present study in terms of fluency ran against the findings of studies such as (Foster \& Skehan, 1996, 1997; Skehan \& Foster, 1999; Tavakoli \& Skehan, 2005) who reported that task structure led to the production of more fluent language.

Regarding the complexity of 12 learners' written production and the effect of generic features of task on this domain of written production, the findings of the study indicated that generic features of task did not have a significant effect on 12 learners' written production in terms of complexity. The findings of the present study in terms of complexity of written production are in line with the findings of the research conducted by Skehan \& Foster (1999), Tavakoli \& Foster (2008), and Rahimpour \& Mehrang (2010) who found that task structure has no effect on L2 learners' oral performance in terms of complexity. The findings of this study in terms of complexity; however, ran against the findings of studies done by researchers like Tavakoli \& Skehan (2005).

\section{REFERENCES}

[1] Barton, D. \& Hamilton, M. (1998). Local Literacies. London: Routledge.

[2] Bhatia, V. (2002). Applied genre analysis: analytical advances and pedagogical procedures. In: Johns, A. (Ed.), Genre in the Classroom. Lawrence Erlbaum Johns, Mahwah, NJ, pp. 279-283.

[3] Bloor, M. (1998). English for specific purposes: The preservation of the species (Some notes on recently evolved species and on the contribution of John Swales to its preservation and protection). English for Specific Purposes, 17, 47-66.

[4] Dadashpour, S. (2011). The Effects of Task Complexity on EFL Learners' Written Performance. Unpublished master's thesis, Islamic Azad University, Maragheh Branch, Maragheh, Iran.

[5] Dudley-Evans, T. (1986). Genre analysis: an investigation of the introduction and discussion sections of M. Sc. dissertations. In Coulthard, M. (ed.) Talking about text. Birmingham: ELR. University of Birmingham, UK.

[6] Ellis, R. (2003). Task-based language learning and teaching. Oxford: Oxford University Press.

[7] Ellis, R (Ed.) (2005). Planning and task performance in a second language. Amsterdam: John Benjamins. 
[8] Ellis, R. (2008). The study of second language acquisition. Oxford: Oxford University Press.

[9] Ellis, R. (2009). Task-based language teaching: Sorting out the misunderstandings. International Journal of Applied Linguistics Vol. 19, 3. pp: 229-246.

[10] Foster, P., \& Skehan, P. (1996). The influence of planning and task type on second language performance. Studies in Second Language Acquisition, 9, 12-20.

[11] Foster, P., \& Skehan, P. (1999). The influence of planning and focus of planning on task-based performance. Language Teaching Research 3, 215-247.

[12] Gee, J. (1996). Social linguistic and literacy (2 ${ }^{\text {nd }}$ Ed.).London: Taylor \&Francis.

[13] Hyland, K. (2002). Genre: Language, context, and literacy. Annual Review of Applied Linguistics (2002), 22. 113-135.

[14] Hyland, K. (2003). Genre-based pedagogies: A social response to process. Journal of Second Language Writing, 12, 17-29.

[15] Iwashita, N., McNamara, T., \& Elder, C. (2001). Can we predict task difficulty in an oral proficiency test? Exploring the potential of an information-processing approach to task design. Language Learning, 51(3), 401-436.

[16] Long, M. (1985). A role for instruction in second language acquisition: task-based language teaching. In K. Hyltenstam \& M. Pienemann (Eds.), Modelling and assessing second language acquisition (pp.77-99). Clevedon: Multilingual Matters.

[17] Long, M. (Ed.) (2007). Problems in SLA, Mahwah, NJ: Erlbaum.

[18] Rahimpour, M. (1997). Task complexity, task condition, and variation in L2 oral discourse. Unpublished Ph.D. thesis, University of Queensland, Australia.

[19] Rahimpour, M. (1999). Task complexity and variation in interlanguage. In N. O. Jungheim \&P. Robinson (Eds.), Pragmatic and pedagogy: proceeding of the $3^{\text {rd }}$ pacific Second Language Research Forum (pp.115-134). Tokyo, Japan: Pac LRF.

[20] Rahimpour, M. (2002). Factors affecting task difficulty. Journal of the Faculty of Literature and Humanities, Tarbiat Moallem University, 9(33), 1-16.

[21] Rahimpour, M. (2007). Task complexity and variation in L2 learners' oral discourse. Working Papers in Language and Linguistics, University of Queensland, 1-9.

[22] Rahimpour, M. (2008). Implementation of task-based approaches to language teaching. Pazhuhesh-e-Zabanha-ye Khareji Journal, University of Tehran, 41, 45-61.

[23] Rahimpour, M. (2010). Current trends on syllabus design in FL instruction. Procedia Social and Behavioral Sciences. Vol. 2. pp: 1660-64.

[24] Rahimpour, M. \& Mehrang, F. (2010). Investigating Effects of Task Structure on EFL Learner's Oral Performance. English Language Teaching. Vol. 3, No. 4; December 2010.

[25] Robinson, P. (1995). Task complexity and second language narrative discourse. Language Learning, 45(1), 99-140.

[26] Robinson, P. (2001). Task complexity, task difficulty, and task production: exploring interactions in a componential framework. Applied Linguistics, 22(1), 27-57.

[27] Robinson, P. (2003). The cognition hypothesis, task design, and adult task-based language learning. Second Language Studies, 21(2), 45-105.

[28] Robinson, P. (2005). Cognitive complexity and task sequencing: studies in a componential framework for second language task design. International Review of Applied Linguistics, 43, 1-32.

[29] Robinson, P. (2007). Task complexity, theory of mind, and intentional reasoning: effects on L2 speech production, interaction, uptake and perceptions of task difficulty. International Review of Applied Linguistics, 45(3), 193-213.

[30] Salimi, A. \& Dadashpour, S. (2011). The effect of cognitive task complexity on EFL learners' written production. A paper presented at ICEEPSY, 2011, Istanbul, Turkey.

[31] Salimi, A. \& Yousefi, M. (2009). The effect of task complexity on L2 learners' uptake in EFL context. A paper presented at $7^{\text {th }}$ International TELLSI Conference. University of Yazd, October, 20-22.

[32] Skehan, P. \& Foster, P. (1999). The influence of task structure and processing conditions on narrative retellings. Language Learning, 49(1), 93-120.

[33] Swales, J. M. (1990). Genre Analysis. English in academic and research setting. Cambridge: Cambridge University Press.

[34] Tavakoli, P. \& Foster, P. (2008). Task design and second language performance: the effect of narrative type on learner output. Language Learning.58:2, 439-473.

[35] Tavakoli, P. \& Skehan, P. (2005). Strategic planning, task structure and performance testing. In R. Ellis (Ed.), Planning and task performance in a second language (pp. 239 - 277). Amsterdam: Benjamins.

Davud Kuhi is a PhD in applied linguistics. He is currently a faculty member of Islamic Azad University, Maragheh Branch. He has been teaching English for over 10 years for B.A and M.A students in TEFL. His main areas of interest are genre analysis and discourse analysis.

Asghar Salimi is a PhD in applied linguistics. He is currently the chancellor of Payam Nour University, Shahindej Branch. He has been teaching English for over 10 years at several universities for B.A and M.A students in TEFL. He has presented more than ten papers in different national and international conferences in different countries. His main areas of interest are task-based learning and teaching, syllabus design, and Second Language Acquisition (SLA).

Ali Shafaei is an M.A in TEFL. He has experience of teaching in Islamic Azad University as well as Iran National Language Institution. He holds an M.A from Islamic Azad University, Maragheh Branch. His main areas of interest are task-based language teaching and genre analysis. 